\title{
Kebijakan hedging dengan derivatif valuta Asing pada perusahaan go publik Di indonesia periode 2009-2012
}

\author{
Kartini * \\ Rif'ad adista hasridha **
}

\begin{abstract}
This study aims to test the Hedging Policy with Foreign
\end{abstract} Currency Derivatives Companies Go Public In the period 20092012 in Indonesia have hedging dependent variable, and independent variables consist of DER, ICR, MBV, LnTA and CR. The method in this study using a tool such as Regression Logit (Binary Logit) were further tested by assessing the feasibility of the regression model (Goodness of fit test) and a value $R 2$ Karke Nagel. Testing the hypothesis in this research using multiple ways of testing, ie Simultaneous testing using Omnibus Test of Model Coefficients. Partial and testing employ the Wald statistical test method of logistic regression results. The result of the logit regression is used to determine how far influence the policy of hedging the company went public in Indonesia.The results of this study indicate that the independent variables consist of $D E R, I C R$, $M B V, L n T A$ and $C R$ simultaneously affect hedging policy at the company went public in Indonesia. Partially ICR affect the hedging policy of the company went public in Indonesia, while $D E R, M B V, L n T A$ and $C R$ had no effect on the hedging policy of the company went public in Indonesia..

Keywords: DER, ICR, MBV, LnTA, CR and Hedging.

\section{Pendahuluan}

Perdagangan internasional adalah salah satu motor penggerak bagi pertumbuhan perekonomian. Keterlibatan dengan aktivitas internasional menyebabkan perusahaan harus menghadapi risiko keuangan karena adanya perubahan kurs mata uang mata yang disebabkan oleh perubahan 
jumlah permintaan dan penawaran akan mata uang.hedging adalah tindakan yang dilakukan untuk melindungi sebuah perusahaan atau trader dari exposure terhadap fluktuasi nilai tukar (Berlianta, 2004). Fungsi dari hedging yaitu memperkecil atau menghilangkan resiko kerugian atas ketidakpastian harga yang mungkin terjadi pada saat transaksi di pasar fisik akan dilakukan nanti. Dengan melakukan hedging, maka apabila harga yang terjadi di pasar fisik nantinya tidak sesuai dengan yang diharapkan, maka kerugian yang terjadi akan ditutupi oleh keuntungan yang diperoleh atas transaksi yang dilakukan di bursa berjangka(Shapiro (1999:144), Eiteman (2003:173-174)).

Perkembangan dunia investasi yang semakin pesat tidak hanya diindikasikan oleh banyaknya jumlah uang dan investor yang berperan dalam dunia investasi. Kemajuan investasi juga dapat dilihat dari banyaknya alternatif investasi di bursa dan salah satunya adalah derivatif. Derivatif merupakan suatu instrumen keuangan atau suatu kesepakatan antara dua pihak, yang mempunyai suatu nilai tertentu yang ditetapkan berdasarkan harga sesuatu yang lain(Mc.Donald, 2003).

Dilihat dari sejarahnya, transakasi derivatif sebenarnya dimulai dari komoditas, namun karena dapat diterapkan di pasar uang produk derivatif berkembang. Sebagaimana disampaikan Ketua Badan Pelaksana Bursa Komoditi (Bapepti), perdagangan fisik komoditas memang semakin kurang diminati, baik di pasar Indonesia maupun di pasar dunia.

Aplikasi kebijakan hedging dengan instrumen derivatif valuta asing semakin meningkat pesat dalam dua dekade terakhir di negaranegara maju. Namun temuan riset-riset empiris mengenai determinan kebijakan hedging masih relatif terbatas, dan membutuhkan riset lebih luas terutama di negara-negara berkembang. Determinan kebijakan 
hedging sangat bervariasi antar negara karena tergantung karakteristik unik masing-masing negara. Sejauh ini tidak banyak produk derivatif yang sesuai dengan kondisi Indonesia. Dibutuhkan pendekatan koordinatif semua otoritas moneter untuk mensosialiasikan aktifitas derivatif. Masih banyak pembeli derivatif yang belum menyadari potensi keuntungan dan resiko dari transaksi derivatif. Bahkan lembaga bank dan perusahaan multinasional di Indonesia tidak dapat melakukan hedging untuk valuta asing dan suku bunga lebih dari satu tahun karena tidak ada utang jangka panjang yang berbunga tetap dan instrumen investasinya (Gunawan, 2003).

Resiko terbesar dari transaksi multinasional ditimbulkan oleh fluktuasi kurs valuta asing. Fluktuasi kurs valuta asing berdampak langsung pada omset penjualan, penetapan harga produk, serta tingkat laba eksportir dan importir. Fluktuasi kurs valuta asing juga menyebabkan ketidakpastian nilai aset dan kewajiban, serta dapat mengancam kelangsungan hidup perusahaan (Paranita, 2011). Oleh karena itu, untuk mengantisipasi dampak negatif risiko fluktuasi kurs valuta asing serta melindungi kepentingan para pemegang saham, maka perusahaan multinasional melakukan kebijakan Hedging dengan instrumen derivatif.

Hedging sebagai strategi keuangan akan menjamin bahwa nilai valuta asing yang digunakan untuk membayar (outflow) atau sejumlah mata uang asing yang akan diterima (inflow) di masa mendatang tidak terpengaruh oleh perubahan dalam fluktuasi kurs valuta asing. Prinsip dasar hedging dalam hal ini adalah untuk melakukan komitmen penyeimbang dalam valuta asing yang sama, yakni komitmen kedua untuk sejumlah yang sama dari komitmen awal namun berlawanan tanda(Faisal, 2001). 
Hedging sebagai strategi keuangan akan menjamin bahwa nilai valuta asing yang digunakan untuk membayar (outflow) atau sejumlah mata uang asing yang akan diterima (inflow) di masa mendatang tidak terpengaruh oleh perubahan dalam fluktuasi kurs valuta asing. Prinsip dasar hedging dalam hal ini adalah untuk melakukan komitmen penyeimbang dalam valuta asing yang sama, yakni komitmen kedua untuk sejumlah yang sama dari komitmen awal namun berlawanan tanda. Orisinalitas penelitian ini terletak pada penekanan adanya integrasi terhadap konsep kebijakan hedging dengan instrumen derivatif valuta asing pada data panel yang diuji dengan model regresi logistik, sekaligus menjelaskan integrasi financial distress hypotesis, underinvestment problem hypotesis, dan assets substitution problem hypotesis (Paranita, 2011).

Perusahaan menerapkan kebijakan hedging untuk mengurangi fluktuasi arus kas dan meminimalkan kondisi financial distress. Mayoritas riset terdahulu menggunakan leverage dan interest coverage ratio sebagai proxy financial distress(Smith dan Stulz, 1985; Haushalter, 2000). Leverage yang lebih tinggi mengindikasikan financial distress costs yang lebih tinggi, sehingga semakin besar juga motivasi perusahaan untuk menerapkan hedging(Graham dan Rogers, 2002; Suriawinata, 2005). Sementara semakin besar interest coverage ratio, mengindikasikan bahwa financial distress cost perusahaan lebih rendah, sehingga semakin rendah pula motivasi untuk melakukan hedging(Geczy et al. 1997; Haushalter, 2000; Davies et al., 2006; Hu dan Wang, 2006; Clark dan Judge, 2008; Schiozer dan Saito, 2009).

Mian (1996) serta Allayannis dan Ofek (2001) mengemukakan bahwa perusahaan dengan oportunitas pertumbuhan yang lebih besar akan 
menghadapi underinvestment costs yang lebih besar, sehingga lebih termotivasi untuk menerapkan kebijakan hedging. Menurut Froot 'et al. (1993), Problem pembiayaan eksternal yang mahal adalah masalah klasik underinvestment, di mana pemegang saham memutuskan untuk menolak proyek beresiko rendah jika mereka menilai bahwa keuntungan ekonomis akan beralih ke kreditur. Manajemen resiko dapat meminimalkan hal ini dengan kebijakan hedging. Underinvestment problem lazimnya dialami perusahaan dengan oportunitas investasi yang besar. Semakin tinggi market-to-book value of equity mengindikasikan semakin besar juga oportunitas investasi suatu perusahaan, sehingga semakin kuat juga motivasi untuk menerapkan kebijakan hedging. Semakin besar size (ukuran) perusahaan, terdapat kecenderungan perusahaan untuk menerapkan kebijakan hedging karena lebih ekonomis (Nance et al., 1993; Mian, 1996; Geczy et al., 1997; Graham dan Rogers, 2002; Suriawinata, 2005).

Kebijakan hedging untuk mengurangi assets substitution problem timbul antara lain dari penggunaan hutang bank. Pemegang saham cenderung memilih proyek yang lebih beresiko. Kreditur menganggapnya sebagai perilaku oportunistik sehingga membebaninya dengan tingkat suku bunga yang tinggi. Perusahaan yang memiliki aset yang likuid cenderung tidak terbebani assets substitution problem dan kurang membutuhkan instrumen hedging karena memiliki substitusi hedging. Dalam hal ini likuiditas diproxy dengan current ratio(Tufano, 1996; Gezcy et al, 1997; Suriawinata, 2005). 
Penelitian ini bertujuan mengembangkan pendekatan empiris sebagai upaya memberikan kontribusi dalam kontroversi teoritis determinan kebijakan hedging dengan instrumen derivatif valuta asing di negara berkembang. Penelitian ini dimaksudkan untuk menjawab fenomena yang terjadi terhadap hasil penelitian sebelumnya dan perkembangan kebijakan hedging dengan instrumen derivatif valuta asing pada perusahaan nonfinansial di Bursa Efek Indonesia.

\section{Landasan Teori}

Menurut Shapiro (1999:144) Hedging merupakan sebuah bagian dari currency exposure yang berarti menentukan sebuah pengganti kerugian kurs mata uang, misalnya kerugian atau keuntungan pada nilai asal currency exposure sebenarnya dapat disamakan dengan keuntungan atau kerugian nilai tukar mata uang pada currency hedge. Menurut Eiteman (2003:171-174) Hedge merupakan pembelian suatu kontrak (termasuk foward exchange) atau barang nyata yang nilainya akan meningkat dan kerugian dari jatuhnya nilai tersebut dari kontrak lain atau barang nyata. Pelaku Hedging berusaha melindungi pemilik dari kerugian.

Menurut Arditti dalam Utomo (2000), derivatif bukanlah sebuah klaim atas arus pendapatan seperti layaknya saham, obligasi, atau reksadana, melainkan merupakan kontrak perjanjian antara dua pihak untuk menjual atau membeli sejumlah barang (baik komoditas maupun sekuritas) pada tanggal tertentu di masa yang akan datang dengan harga yang telah disepakati pada saat ini. Kemudian dalam Surat Keputusan Bank Indonesia No.28/119/KEP/DIR tanggal 29 Desember 1995 mendefinisikan transaksi derivatif sebagai suatu kontrak atau perjanjian pembayaran yang nilainya merupakan turunan dari nilai instrument yang 
mendasari seperti tingkat suku bunga, nilai tukar, komoditi, ekuiti dan indeks, baik yang diikuti dengan pergerakan atau tanpa pergerakan dẩna atau instrumen.

Fungsi utama dari pasar futures adalah untuk mengalihkan atau men-transfer risiko harga dari pihak hedger ke pihak spekulator. Atau, bahwa risiko tersebut dialihkan dari orang yang bersedia membayar untuk menghindari risiko kepada orang yang berani menanggung risiko dengan harapan memperoleh keuntungan.Pada prakteknya aktivitas lindung nilai tidaklah semudah ini. Jumlah kerugian dan keuntungan pada sebuah transaksi lindung nilai akan ditentukan oleh hubungan antara harga spot dan harga futures ketika sebuah transaksi lindung nilai itu dimulai dan diselesaikan. Selisih dari harga spot dan harga futures dinamakan basis.

Pada dasarnya, bank berfungsi sebagai penghimpun dana dari masyarakat yang mempunyai dana lebih dan menyalurkannya kepada masyarakat yang kekurangan dana. Sumber dana bank terdiri dari deposito (tabungan, deposito berjangka, dan giro), sekuritas, dan modal. Dalam menggunakan dananya, bank menyalurkan dana yang telah dihimpunnya melalui cash reserves (cadangan kas), loan (kredit), securities (sekuritas), dan other assets (asset lainnya). Sekuritas adalah suatu bentuk kepemilikan atau surat berharga yang berguna untuk mendapatkan bagian dari suatu kekayaan yang menerbitkan surat berharga ini. Sekuritas merupakan salah satu penggunaan dana bank yang mémberikan keuntungan terbesar setelah loan. Pasar uang merupakan salah satu tempat jual beli sekuritas yang dimanfaatkan oleh bank untuk memperoleh keuntungan. 
Sementara hedging adalah tindakan yang dilakukan untuk mengurangi atau bahkan menghilangkan risiko yang terkait dari langkah tertentu yang diambil seseorang. Dalam pasar uang, hal ini banyak dilakukan untuk mengurangi potensi kerugian yang mungkin timbul dari risiko investasi yang dilakukan. Hedging timbul didasari oleh ketidakpastian akan masa yang akan datang. Semua ketidakpastian mendorong seseorang untuk melakukan suatu tindakan guna mengurangi risiko yang ada. Dalam paper ini penulis akan menjelaskan hubungan antara pasar uang dan hedging.

Hedging sering terjadi di pasar uang karena pasar uang sangat berfluktuatif, per menit bahkan per detik. Hedging terjadi ketika membeli sekuritas di pasar uang pada waktu tertentu. Lalu beberapa detik kemudian, harga sekuritas itu sudah berubah, baik naik atau turun. Jika naik, mungkin ada beberapa perusahaan yang lebih memilih untuk hedging. Dalam hal ini, pembeli sekuritas berharap harganya bisa naik lagi. Jika harga sekuritas tersebut turun, ada beberapa perusahaan yang lebih memilih hedging. Hal ini diharapkan agar harganya bisa naik kembali. Inilah hubungan antara pasar uang dan hedging.

\section{Metode Penelitian}

1) Populasi dan Sampel

Sumber data dalam penelitian adalah Bursa Efek Indonesia. Data yang diperlukan untuk menguji hipotesis dalam penelitian ini adalah :

Kinerja dari perusahaan nonfinansial di sektor manufaktur selama 4 tahun yang ditunjukkan dengan rasio keuangan. Untuk mendapatkan informasi yang dibutuhkan dilakukan proses pengumpulan data melalui 
dokumentasi yang merupakan data tertulis yang berhubungan dengan objek penelitian. Untuk metode pengumpulan data dilakukan dengan cara membuat salinan dan mengumpulkan arsip serta catatan-catatan perusahaan yang ada.Data yang dibutuhkan terdiri dari data sekunder. Data mengenai rasio keuangan diperoleh dari Laporan Tahunan Annual Report dari Pojok Bursa FEथII Yogyakarta.

2) Jenis dan Tekhnik Pengumpulan Data

Teori ini diperoleh dari literatur, artikel, jurnal dan hasil penelitian terdahulu.Metode ini digunakan untuk mempelajari dan memahami literatur - literatur yang memuat pembahasan yang berkaitan dengan penelitian. Data yang digunakan dalam penelitian ini dikumpulkan dengan metode dokumentasi yang dilakukan dengan mempelajari dokumen - dokumen atau data yang dibutuhkan, dilanjutkan dengan pencatatan dan perhitungan.

3) Metode Analisis Data

a. Riset ini mengaplikasikan Logistic Regression untuk menganalisis kebijakan hedging dengan instrument derivative valuta asing. Logistic Regression digunakan untuk menguji apakah probabilitas terjadinya variable dependen dapat diprediksi dengan variable independen.Logistic Regression lazimnya diterapkan ketika variable dependen berupa non metricatau kategori, dan asumsi multivariate normal distribution tidak terpenuhi (Ghozali, 2006). Dalam riset ini, variable dependennya adalah binary variable, yaknidummy aktifitas hedging dengan instrument derivative valuta asing 
(DHEDG).Adapun variable independennya adalah Debt to Equity Ratio (DER), Interest Coverage Ratio (ICR), Marketto-Book Value of Equity (MBV),Natural Log of Total Assets (LnTA),dan Current Ratio (Cr). Untuk.Analisis ini secara matematis ditulis dengan persamaan sebagai berikut :

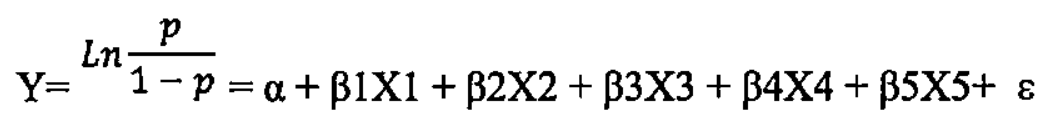

Apabila koefisien $\beta$ bernilai positif $(+)$ maka terjadi pengaruh searah antara variabel independen dengan variabel dependen, demikian pula sebaliknya, bila koefisien bernilai negatif (-) hal ini menunjukkan adanya pengaruh negatif dimana kenaikan nilai variabel independen akan mengakibatkan penurunan nilai variabel dependen.

b. Menilaikelayakan model regresi (Goodness of fit test)

Denganmemperhatikan

output

dariHosmerdanLemeshowdenganhipotesis :

$\mathrm{HO}$ = tidak ada perbedaan nyata antara klasifikasi yang diamati

$\mathrm{HA}=$ ada perbedaan nyata antara klasifikasi yang diprediksi dengan klasifikasi yang diamati.

Dasar pengambilan keputusanya itu dengan memperhatikan nilai I yang diukur dengan nilai chi-square pada bagian bawah uji Hosmer dan Lemeshow :

a. Jikaprobabilitas $>0,05 \mathrm{H} 0$ diterima

b. Jikaprobabilitas $<0,05$ H0 ditolak

c. Nilai Nagel Karke $\mathrm{R}^{2}$ 
Nagel Karke R Square merupakan modifikasị dari koefisien Cox dan Snell's untuk memastikan bahwa nilainya bervariasi dari 0 sampai 1 . Hal ini dilakukan dengan cara membagi nilai Cox dan Snell's $\mathrm{R}^{2}$ dengan nilai maksimumnya.

4) Hipotesis

\section{a. Pengujian Secara Parsial}

Pengujian secara parsial digunakan untuk mengetahui pengaruh masing-masing variabel independen terhadap variabel dependen. Pengujian ini menggunakan uji statistik Wald dari hasil regresi logistik. Pengambilan keputusan dalam pengujian ini adalah jika nilai Pvalue statistik Wald lebih kecil dari nilai tingkat signifikansi $5 \%$ maka dapat disimpulkan terdapat pengaruh antara variabel independen terhadap variabel dependen, maka hipotesis diterima. Sebaliknya jika nilai Pvalue statistik Wald lebih besar dari nilai tingkat signifikansi 5\% maka dapat disimpulkan tidak dapat pengaruh antara variabel independen terhadap variabel dependen, maka hipotesis ditolak.

$$
\begin{aligned}
& \mathrm{HO}: \beta \mathrm{i}=0 \\
& \mathrm{H} 0: \beta \mathrm{i} \neq 0
\end{aligned}
$$

\section{A. Analisis dan Pembahasan}

Hipotesis pertama penelitian ini menyatakan bahwa Debt to equity ratio berpengaruh positif terhadap kebijakan hedging. Besarnya koefisien regresi DERyaitu 0,183 dan nilai pvalue $=$ 0,307 . Pada tingkat signifikansi $\alpha=5 \%$; maka koefisien regresi tersebut tidak signifikan karena $\rho=0,370>0,05$, sehingga $\mathrm{H} 1$ ditolak yang dapat berarti bahwa Debt to equity ratio tidak 
berpengaruh positif terhadap kebijakan hedging sehingga hipotesis pertama penelitian ini ditolak.

Hipotesis kedua penelitian ini menyatakan bahwa Interest coverage ratio berpengaruh positif terhadap kebijakan hedging. Besarnya koefisien regresi ICRyaitu 0,126 dan nilai pvalue $=0,006$. Pada tingkat signifikansi $\alpha=5 \%$; maka koefisien regresi tersebut signifikan karena $\rho=0,006<0,05$, sehingga $\mathrm{H} 2$ diterima yang dapat berarti bahwa Interest coverage ratio berpengaruh positif terhadap kebijakan hedging sehingga hipotesis kedua penelitian ini diterima.

Hipotesis ketiga penelitian ini menyatakan bahwa Market-to-book value of equity berpengaruh positif terhadap kebijakan hedging. Besarnya koefisien regresi MBVyaitu 0,008 dan nilai pvalue $=0,929$. Pada tingkat signifikansi $\alpha=5 \%$; maka koefisien regresi tersebut tidak signifikan karena $\rho=0,929>$ 0,05 , sehingga $\mathrm{H} 3$ ditolak yang dapat berarti bahwa Market-tobook value of equity tidak berpengaruh positif terhadap kebijakan hedging sehingga hipotesis ketiga penelitian ini ditolak.

Hipotesis keempat penelitian ini menyatakan bahwa Natural $\log$ of total assets berpengaruh positif terhadap kebijakan hedging. Besarnya koefisien regresi LNTAyaitu 0,339 dan nilai $\rho v a l u e=0,075$. Pada tingkat signifikansi $\alpha=5 \%$; maka koefisien regresi tersebut tidak signifikan karena $\rho=$ $0,0075>0,05$, sehingga $\mathrm{H} 4$ ditolak yang dapat berarti bahwa Natural $\log$ of total assets tidak berpengaruh positif terhadap 
kebijakan hedging sehingga hipotesis keempat penelitianini ditolak.

Hipotesis kelima penelitian ini menyatakan bahwa current ratio berpengaruh positif terhadap kebijakan hedging. Besarnya koefisien regresi CRyaitu 0,512 dan nilai pvalue $=$ 0,302 . Pada tingkat signifikansi $\alpha=5 \%$; maka koefisien regresi tersebut tidak signifikan karena $\rho=0,302>0,05$, sehingga $\mathrm{H} 5$ ditolak, berarti bahwa current ratio tidak berpengaruh positif terhadap kebijakan hedging sehingga hipotesis kelima penelitian ini ditolak.

\section{Kesimpulan}

Kesimpulan yang dapat diambil dari penelitian ini adalah sebagai berikut :

1. H1 ditolak,Debt to equity ratio tidak berpengaruh signifikan terhadap kebijakan hedging. Hasil ini dapat diartikan bahwa besar kecilnya DER tidak akan mempengaruhi kebijakan hedging perusahaan.

2. H2 diterima yang dapat berarti bahwa Interest coverage ratio berpengaruh positif terhadap kebijakan hedging. Hasil ini dapat diartikan bahwa semakin tinggi Interest coverage ratio maka kebijakan hedging perusahaan juga akan semakin besar.

3. H3 ditolak,Market to Book Value of Equitytidak berpengaruh signifikan terhadap kebijakan hedging. Hasil ini dapat diartikan bahwa besar kecilnya Market to Book Value of Equity tidak akan mempengaruhi kebijakan hedging perusahaan. 
4. H4 ditolak,Natural of Log Assets atau Ukuran perusahaan tidak berpengaruh terhadap kebijakan hedging. Hasil ini dapat diartikan bahwa besar kecilnya ukuran perusahaan tidak akan mempengaruhi kebijakan hedging perusahaan

5. H5 ditolak,Current ratio tidak berpengaruh terhadap kebijakan hedging. Hasil ini dapat diartikan bahwa besar kecilnya current ratio tidak akan mempengaruhi kebijakan hedging perusahaan.

\section{Kendala dan Kritik}

1. Kelemahan dan kendala yang ditemui oleh peneliti di dalam melakukan penelitian ini adalah menentukan katagori perusahaan yang melakukan aktifitas hedging dan tidak melakukan aktifitas hedging pada data laporan tahunan keuangan konsolidasi perusahaan nonfinansial yang di informasikan dalam masing-masing data perusahaan yang diteliti. Karena didalam data yang digunakan perusahaan yang melakukan aktifitas hedging hanya menjelaskan tentang cara dan persyaratan perusahaan yang melakukan aktifitas hedging. Sedangkan bagi perusahaan yang tidak melakukan aktifitas hedging tidak menjelaskan dan memberikan informasi apapun tentang hedging pada laporan tahunan keuangan konsolidasi tersebut.

2. Masih minimnya pengembangan teori yang menjelaskan analisis regresi logit secara detail sehingga peneliti kesulitan dalam mencari referensi untuk melakukan penelitian ini. 


\section{Saran}

Saran yang diajukan peneliti adalah sebagai berikut:

1. Bagi perusahaan yang akan melakukan pengambilan instrumen derivatif sebagai sarana hedging diharapkan untuk memperhatikan informasi internal perusahaan yakni Interest coverage ratio. Hal ini perlu dilakukan dikarenakan mencegah perusahaan mendapat risiko eksposur valuta asing yang seharusnya dapat dialihkan oleh penggunaan instumen derivatif sebagai sarana hedging, dan mencegah perusahaan untuk mengeluarkan biaya derivatif dengan tidak memberikan manfaat yang diharapkan.

2. Bagi investor yang akan melakukan investasi ke berbagai perusahaan manufaktur dengan yang terdaftar di Bursa Efek Indonesia dapat memperhitungkan terlebih dahulu variabel Interest coverage ratio yang dimiliki perusahaan tersebut. Bila nilai yangditunjukkan oleh perhitungan variabel tersebut menunjukkan angka yang relatif tinggi dibandingkan dengan perusahaan lain, namun perusahaan tersebut belum melakukan aktivitas hedging maka perusahaan tersebut berisiko terjadinya kesulitan keuangan karena risiko yang diterima perusahaan lebih besar. 


\section{Daftar Pustaka}

Allayannis, George., and E. Ofek., 2001, "Exchange Rate Exposure, Hedging, and The User of Foreign Currency Derivatives", Journal of International Money and Finance, Vol. 20, No. 2, pp. 273-296.

Berlianta, Heli Chandra. 2004. Mengenal Valuta Asing. Gadjah Mada University Press.Yogyakarta.

Brealey, Richard A., 2006, Dasar-dasar Manajemen Keuangan Perusahaan, Erlangga. Jakarta

Faisal, M. 2001. Manajemen Keuangan Internasional. Edisi Pertama. Salemba Empat.

Froot, K.A., D.S. Scharfstein dan J.C. Stein (1993), Risk Management : Coordinating Corporate Investment and Financing Policies, Journal of Finance 48 (5), pp.16291658.

Gay, G.D. dan J. Nam (1998), The Underinvestment Problem and Corporate Derivatives Use, Financial Management 27 (4), pp. 53-69.

Geczy, Christopher., Minton, Bernadette A., and Schrand, Catherine., 1997, "Why Firms Use Currency Derivatives", The Journal of Finance, Vol. LII, No. 4, September, hal. 1323-1354.

Ghozali, I. 2006. Aplikasi Analisis Multivariate dengan Program SPSS. Badan PenerbitUniversitas Diponegoro. Semarang.

Graham, John R., and Rogers, Daniel A., 2002, "Do Firms Hedge in Response to Tax Incentives?", The Journal of Finance, Vol. LVII, No. 2 April, hal 815-839.

Gunawan, Itjang D. 2003. Transaksi Derivatif, Hedging, dan Pasar Modal. Grasindo.Jakarta.

Haushalter, G.D. (2000), Financing Policy, Basis Risk, and Corporate Hedging : Evidence from Oil and Gas Producers, The Journal of Finance 55 (1), pp. 107-152.

Kleinbaum, David G. et all. 1987. Applied Regression Analysis and Other Multivariable Methods. Second Edition. PWSKENT Publising Company. Boston.

McDonald, Robert L. 2003. Derivatives Market. Addison Wesley. 
Mian, Shenhzad L., 1996, "Evidence on Corporation Hedging Policy", Journal of Financial and Quantitative Analysis, Vol.31, No.3, Sept, hal.419-439.

Nance, Deana R., Smith, Clifford W., Jr., and Smithson, Charles W., 1993, "On the Determinants of Corporate Hedging", The Journal of Finance, Vol. XLVIII, No. 1, March, hal. 267-284.

Paranita, Ekayana Sangkasari, 2006, "Analisis Pengaruh Kebijakan Hedging Dengan Instrumen DerivatifValuta Asing Dan Variabel-Variabel Value Drivers Terhadap Nilai Pemegang Saham", Jurnal Bisnis Strategi, Vol. 15/ No. 1/Juli 2006.

Paranita, E.S (2011), Kebijakan Hedging dengan Derivative

ValutaAsingPada Perusahaan Publik di Indonesia Tahun 2007-2010: Seminar

NasionalllmuEkonomiTerapanFakultasEkonomi UNIMUS 2011.

Shapiro (1999:144) danEiteman (2003:173-174) "Hedging" http://3yoo.wordpress.com/2011/12/03/hedging/! Desember 2011.

Smith, C, W., and R. M. Stulz, 1985, The determinants of firms' hedging policies, Journal of Financial Economics 7, 117161.

Suriawinata, Iman S., 2004, “Apakah Kebijakan Hedging Perusahaan dengan Instrumen Derivatif Valuta Asing Dapat Meningkatkan Nilai Pemegang Saham?", Jurnal Manajemen Prasetiya Mulya, Vol. 9, No. 2, November, hal. 59-80.

Tufano, Peter., 1996, "Who Manages Risk? An Empirical Examination of Risk Management Practices in the Gold Mining Industry", The Journal of Finance, Vol. LI No. 4, September, hal. 1097-1137.Jakarta. 